\title{
Pilot Çalışma: Manda Sütünde Toxocara vitulorum Larva Varlığının Araştırılması
}

\author{
Ali Tümay Gürler ${ }^{1}$, Hande Gürler² \\ ${ }^{1}$ Ondokuz Mayls Üniversitesi, Veteriner Fakültesi, Parazitoloji Anabilim Dall, ORCIDD: 0000-0001-8092-1245 \\ ${ }^{2}$ Ondokuz Mayls Üniversitesi, Veteriner Fakültesi, Doğum ve Jinekoloji Anabilim Dall, ORCiD: 000-0001-7239-5388
}

Geliş Tarihi / Received: 08.03.2018, Kabul Tarihi / Accepted: 17.04.2018

\begin{abstract}
Özet: Toxocara vitulorum buzağı ve malaklara primer galaktojen yolla bulaşan, erginleri incebağırsağa yerleşen, patojen bir nematoddur. Bu pilot çalışmada, manda sütünde parazitin larvaları aranmıştır. Araştırma süresince 40 mandaya ait süt örnekleri kullanılmıştır. Tüm süt örnekleri öncelikle mikroskobik olarak siewing-flotasyon yöntemi ile Toxocara sp. larvası bakımından muayene edilmiştir. Daha sonra larvaya rastlanmayan örneklerden rastgele 20 farklı mandaya ait süt örnekleri seçilmiş ve moleküler olarak incelenmiştir. Çalışma sonunda hiçbir süt örneğinde parazitin larvasına ya da DNA'sına rastlanmamıştır. Bu araştırma Türkiye'de manda sütünde Toxocara vitulorum larvası taranması yönünde ilk çalışma niteliğinde olmuştur.
\end{abstract}

Anahtar kelimeler: Toxocara vitulorum, larva, manda, süt

\section{A Pilot Study: Investigation of Toxocara vitulorum Larvae in Water Buffale Milks}

\begin{abstract}
Toxocara vitulorum is a patogen nematoda which infects calves and buffalo calves lactogenically and grows in the small intestine. In the study, infective larvae of the parasite were investigated in water buffalo milks. Forty water buffalo milks were collected and examined used sieving-flotation method. Then, 20 samples randomly selected were analysed molecularly to find DNA of T. vitulorum larvae. In the end of the study, there was no larvae or its' DNA in the milk samples. This is the first study on investigation of $T$. vitulorum larvae in water buffalo milk.
\end{abstract}

Key words: Toxocara vitulorum, larvae, water buffalo, milk

\section{Giriş}

Mandacılık, başta manda sütü ve kaymağı olmak üzere, manda eti ve manda boynuzu gibi çeşitli ürünler elde etmek için yapılan, ülkemizde değeri son yıllarda artan bir sektörüdür. TÜİK verilerine göre manda sayısı Türkiye'de son 10 yılda neredeyse iki katına çıkarak 2017 yılında 161.439'a ulaşmıştır [22]. Samsun ili ve çalışmanın yapıldı̆̆ 1 Kızılırmak Deltası ise mandacılık faaliyetinin en çok yapıldığ 1 yerlerdendir.

Mandalar çevre şartlarına sığırlara oranla daha dayanıklı hayvanlardır. Gebelik süreleri ise ineklerden uzun olmakla birlikte nehir ve bataklık mandalarında sırayla 305-320 ve 320-340 gün arasındadır [9]. İneklerden farklı olarak veteriner hekime ihtiyaç duymadan doğum yapan mandalar, malaklarının ilk bakımlarını da kendileri üstlenirler. Sonbahar-kış aylarında doğan malaklar annelerinden ayrılmazlar. Yetiştiriciler genellikle yeni doğum yapmış mandaları ilk ay sağmazlar ve malakların annele- rini emmelerine izin verirler. İnek yetiştiriciliğinde farklı olan bu uygulama ile hem malaklara oldukça düşkün anne manda yavrusunda ayrılmamış olur, hem de malaklar kolostrumu ile tam olarak beslenmiş olurlar. Kolostrum malakların gelişimleri için oldukça önemli bir besin kaynağ1 olduğu için bu uygulama gereklidir. Ancak kolostrum anne mandadan yavrusuna geçen Toxocara vitulorum için de esas bulaş kaynağıdır [2,6]. Büyük ruminantların en önemli patojen nematodlarından birisi olan parazit ergin hayvanlarda hastalık oluşturmazken, buzağ 1 ve malaklarda önemli patolojik bozukluklara sebep olabilmektedir. Genel olarak sığırlara oranla hastalıklara daha dayanıklı olan mandalar, farklı olarak askaridiosise daha duyarlıdırlar. Hastalığın hem prevalans1 hem de patojenitesi mandalarda daha fazladır. Alınan larva sayısı ile doğru orantılı olarak patojenite de artmakta, fazla sayıda parazit malaklarda ölüme neden olabilmektedir $[8,12,18,21]$.

Askaritlerin biyolojik döngüsü konağın yaşına ve enfektif formun alınışına göre farklılık gösterir. 
Konak 6 aylıktan küçük ise alınan enfektif formların çoğu bağırsaklarda ergin hale geçerler. Bu durum konağın immun sisteminin gelişmesi ile ters orantılı olarak devam eder. İmmun sistemi gelişmiş olan hayvanlarda ise dışarıdan alınan enfektif formlar gelişme göstermeden kaslarda inhibisyona geçmektedir. Gebelik esnasında ise immun sistemin baskılanması ile birlikte bu larvalar tekrar aktive olurlar. Mandalarda kaslardaki larvaların 5 aydan fazla canlı kaldığı, bu sürenin iki doğum süresince devam edebildiği bilinmektedir. Mandalarda gebeliğin 8. ayından sonra inhibe larvalar aktive olmaya başlarlar. Bunlardan önemli bir kısmı meme bezlerine geçer ve malaklar tarafından alınmayı beklerler. Meme bezlerine larva akışı doğum sonrası yaklaşık bir ay devam eder. Bu sürenin uzayabileceği de bilinmektedir. Malaklar tarafindan süt emme sırasında alınan enfektif $L_{3}$ viseral göç geçirmeden direkt olarak bağırsaklarda gelişir. Malaklarda da enfeksiyon genel olarak bu şekilde olmaktadır. Yapılan çalişmalarda, plasental yolla fötusa larva geçişmesiyle ya da enfekte yumurtanın oral alınmasıyla malakların enfekte olmadığı bildirilmektedir $[2,6]$.

Canlı hayvanlarda parazitin tanısı dışkı bakısı ile kolaylıkla yapılabilmektedir [7,11]. Ancak parazitin yumurtası malaklarda en erken 3-4 haftalıktan sonra görülmeye başlar, yani ilk ay malaklarda parazitin varlığını dışkı bakısı ile tespit etmek oldukça zordur [6]. Erken tanı için farklı bir tanı yöntemi olarak anne mandanın sütü askarit larvası varlığı bakımından muayene edilebilir. Böylece malağa geçmesi muhtemel askarit larva varlığı erken dönemde tespit edilmiş olur. Dünyada manda sütünde askarit larvası aranmasına yönelik çeşitli çalışmalar bulunmakla birlikte [1,20], bu konu ile ilgili Türkiye'de bir araştırma yapılmamıştır. Mevcut iki araştırma ise inek sütünde yapılmıştır [2].

Bu çalışmada, Türkiye'de ilk olarak manda sütünde $T$. vitulorum larvasının varlığının araştırılmas1 amaçlanmıştır.

\section{Materyal ve Metod}

$\mathrm{Bu}$ araştırma Samsun iline bağlı Ondokuz Mayıs ve Bafra ilçelerinde, Eylül 2017-Ocak 2018 tarihleri arasında yapılmıştır. Araştırma materyalini PYO. VET.1901.17.010 nolu proje kapsamında toplanan ve 40 farklı mandadan elde edilen süt örekleri oluş- turmuştur. Mandaların tümünün süt emen malakları olduğu, bu malakların yaşlarının 15 gün - 75 günlük arasında değiştiği hayvan sahiplerinden elde edilen bilgiler 1şığında kaydedilmiştir. Süt örnekleri dört ayrı memeden olacak şekilde ayrı olarak alınmış, çalışma süresince 40 farklı mandadan toplamda 160 süt örneği toplanmıştır.

Öncelikli olarak tüm süt örnekleri mikroskobik olarak T. vitulorum larvası bakımından muayene edilmiştir. $\mathrm{Bu}$ amaçla her manda için ayrı olacak şekilde el yapımı elekler hazırlanmıştır. Her süt numunesi $40 \mu \mathrm{m}$ por çaplı bu eleklerden geçirilmiş, elde edilen tortu flat tüp içine yıkanarak aktarılmış, daha sonra invört mikroskop altında larva varlığ bakımından incelenmiştir.

Moleküler analiz amaciyla ise, negatif bulunan örneklerden rastgele olacak şekilde, 20 farklı mandadan alınan süt örnekleri seçilmiştir. Rastgele seçilen flat tüpler 1500 devirde 5 dakika santrifüj edilmiş ve dipteki tortu $1,5 \mathrm{ml}$ 'lik ependorflara alınarak incelenmek üzere $-20^{\circ} \mathrm{C}$ ' de saklanmıştır.

Saklanan örneklerden genomik DNA ekstraksiyonu için ticari kit (İnvitrogen, PureLink Genomic DNA) kullanılmıştır. Parsiyal ITS1, 5.8S rRNA ve parsiyal ITS2 gen bölgelerinin amplifikasyonu NC5 (5'-GTAGGTGAACCTGCGGAAGGATCATT-3') ve NC2 (5'-TTAGTTTCTTTTCCTCCGCT-3') primer çifti kullanılarak yapılmıştır. Mastermiks her bir reaksiyon için toplam $24 \mu \mathrm{l} ; 2 \mu \mathrm{l}$ genomik DNA, 1xPCR buffer, $2.5 \mathrm{mM} \mathrm{MgCl}, 0.2 \mu \mathrm{M}$ dNTP, $10 \mu \mathrm{M}$ primer ve $1 \mathrm{U}$ Taq polimeraz olacak şekilde ayarlanmıştır $[8,15]$. Amplifikasyon koşulları ilk denatürasyon $95^{\circ} \mathrm{C} 10 \mathrm{dk}$., 40 siklus denatürasyon $95^{\circ} \mathrm{C} 45 \mathrm{sn}$, bağlanma $55^{\circ} \mathrm{C} 45 \mathrm{sn}$, uzama $72^{\circ} \mathrm{C} 45 \mathrm{sn}$ ve son uzama $72^{\circ} \mathrm{C} 5 \mathrm{dk}$ şeklinde programlanmıştır. Elektroforez ile PCR ürünleri, görüntülenmek için, agaroz ile hazırlanan jele eklenmiş, elektrik alanda belirli bir süre boyunca boyutlarına ve moleküler ağırlıklarına göre ayrılmıştır. PCR ürünlerini görüntülemek için \% 2'lik agaroz jel kullanılmıştır.

\section{Bulgular}

İncelemesi yapılan süt örneklerinin hiçbirinde $T$. vitulorum larvasına rastlanmamıştır. Larva negatif örneklerden rastgele seçilerek incelenen süt örneklerinin moleküler analizi sonucunda da parazitin DNA'sı bulunamamıştır. 


\section{Tartışma ve Sonuç}

Toxocara vitulorum malakların en patojen parazitlerinden birisi olarak kabul edilmekle birlikte, büyük ruminantlarda askaridiosis ile ilgili fazla sayıda çalışma bulunmamaktadır. Yapılan çalışmalar incelendiğinde toxocariasis enfeksiyonuna genellikle dişk1 bak1 yöntemlerinin kullanıldığ1 $[4,5,17,19]$, bunun yanında yeni doğum yapmış mandalarda sütte parazitin larvasının arandığı çalışmalar da olduğu görülür $[1,20)$. Dünya genelinde enfeksiyon oranı malaklarda dışkı bakısına göre \%25,5-34 arasında bildirilmiştir $[1,12,17]$. Türkiye'den sığırlarda $T$. vitulorum'un bulunduğu, yayılışının \%0,5-28,9 arasında değiştiği bilinmektedir [2,4,5,6,13]. Mandalarda da parazitin var olduğu bilinmekle birlikte [14,16], malaklarda, mandalarda ya da manda sütünde parazitin varlığına ilişkin bir çalışma olmadığı görülür. Türkiye'de manda parazitlerine yönelik yapılan tek çalışmada 100 mandanın sindirim sistemi incelenmiş, ancak T. vitulorum'a rastlanmadığı kaydedilmiştir [10]. Yapılan bu çalışma Türkiye'de mandalarda sütte $T$. vitulorum'un varlığına yönelik olarak yapılan ilk araştırma niteliğindedir.

Malaklar için esas enfeksiyon kaynağı anne sütündeki T. vitulorum larvasıdır. Sütte larva yoğunluğu doğum öncesi 8. günden itibaren başlar, doğum sonrası azalarak devam eder. Sütte larva bulunmas1 esas olarak ilk ay olmakla birlikte, devam eden süreçte de larvaya rastlandığı kaydedilmiştir [6]. Türkiye'de sütte $T$. vitulorum larvası aranmasina yönelik yapılan çalışmalarda, Adanır (2004) incelediği 450 inek süt örneğinden yalnız $1(\% 0,2)$ 'inde, Akyol (1991) da incelediği 144 inek sütünün 1'inde larva bulunduğu kaydetmiştir [2,3]. Bizim yapt1ğımız çalışmada ise incelemesi yapılan 40 manda sütünün hiçbirinde $T$. vitulorum larvası'na rastlanmamıştır. Pozitif örnek bulunmamasında, örnek sayısının azlığı ve süt örneği alınan dişi mandaların doğum sonrası erken dönemde olmaması göz önünde bulundurulmalıdır.

Sonuç olarak, Türkiye mandacılık faaliyetleri açısından uygun bir coğrafyaya sahiptir ve mandac1lığa/manda ürünlerinin tüketimine olan ilgi artmaktadır. Ancak manda hastalıklarına yönelik yapılan araştırmalar oldukça yetersizdir. Her ne kadar hiçbir manda sütünde $T$. vitulorum larvası'na tesadüf edilmese de, yapılan bu çalışma ülkemiz için ilk araştır- ma niteliğinde olması bakımından önem arz etmektedir. Malak yetiştiriciliğinde önemli bir problem olan askaridiosis ile ilgili olarak Türkiye'de benzer ama daha kapsamlı çalışmalar yapılmalıdır. Her ne kadar bu pilot araştırmada manda sütünde parazitin larvasına rastlanmamıș olsa da, malaklarda, mandalarda ve manda sütünde parazitin ne oranlarda var olduğu tespit edilmelidir. Dünyada malaklarda önemli bir problem olduğu bilinen toxocariasis ile ilgili olarak manda yetiştiricileri arasında farkındalık oluşturulmalı ve mandacılıkta düzenli olarak askaridiosisin tanısı, tedavisi ve korunması ile ilgili bir prosedür geliştirilmelidir.

\section{Kaynaklar}

1. Abdel-Rahman MAM, El-Ashmawy WR, (2013). Toxocara vitulorum in faeces, serum and milk of buffaloes in Giza Governorate. Int J Live Res. 3, 89-99.

2. Adanır R, (2004). Ankara yöresi sığırlarında Toxocara vitulorum prevalansının saptanması. Doktora Tezi, AÜ Sağlık Bilimleri Enstitüsü, Ankara.

3. Akyol V, (1991). Bursa yöresi sı̆̆ırlarında Toxocara (Neoascaris) vitulorum'un epidemiyolojisi. Doktora Tezi, Uludağ Üniv. Sağlık Bilimleri Enstitüsü, Bursa.

4. Arslan MÖ, Sarı B, Taşçı GT, Aktaş MS, (2008). Erzurum yöresinde buzağılarda Toxocara vitulourm yaygınlığ Kafkas Üniv Vet Fak Derg. 14, 37-40.

5. Avcıŏlu H, Balakaya İ, (2011). Prevalence of Toxocara vitulorum in calves in Erzurum, Turkey. Kafkas Üniv Vet Fak Derg. 17, 345-347.

6. Aydenizöz M, (2012). Ascaridiosis. Turk Klin J Vet Sci. 3, 103-108.

7. Borgsteede FHM, Holzhauer M, Herder FL, VeldhuisWolterbeek EG, Hegeman C, (2012). Toxocara vitulorum in suckling calves in the Netherlands. Vet Parasitol. 92, 254-256.

8. Chelladurai JJ, Bader C, Snobl T, Magstadt D, Cooper V, Brewer MT, (2015). Toxocara vitulorum inefection in a cohort of beef calves in Iowa. Vet Parasitol. 214, 96-99.

9. Çelik HA, Özenç E (2015). Çiftlik Hayvanlarında Doğum ve Jinekoloji. Semacan A, Kaymaz M, Fındık M, Rişvanlı A, Köker A. eds. Medipres, s:609.

10. Çetindağ M, Doğanay A, (1996). Samsun yöresi mandalarında sindirim sistemi helmintleri. Etlik Vet Kont Derg. 8, 128-133.

11. Davilla G, Irsik M, Greiner EC, (2010). Toxocara vitulorum in beef calves in North Central Florida. Vet Parasitol. 168, 261-263.

12. Dorny P, Devleesschauwer B, Stoliaroff V, Sothy M, Chea R, Chea B, Sourloing H, Samuth S, Kong S, Nguong K, Sorn S, Holl D, Vercruysse J, (2015). Prevalence and associated risk factors of Toxocara vitulorum infections in 
buffalo and cattle calves in three provinces of central cambodia. Korean J Parasitol. 53, 197-200.

13. Kozan E, (2014). Bartın yöresi sığırlarında dışkı bakısı ile tespit edilen helmintler. T Parazitol Derg. 38, 17-21.

14. Merdivenci A, (1971). Neoascaris vitulorum'un evrimi üzerine, Türk Vet Hek Dern Derg. 41, 20-26.

15. Newton LA, Chilton NB, Beveridge I, Hoste H, Nansen P, Gasser RB, (1998). Genetic markers for strongylid nematodes of livestock defined by PCR-based restriction analysis of spacer rDNA. Acta Trop. 69, 1-15.

16. Oytun HŞ, (1961). Genel parazitoloji ve helmintoloji ders kitabı. Üçüncü Bask1. Ankara: Ege Matbaası, p.365.

17. Rast L, Lee S, Nampanya S, Toribio JA, Khounsy S, Windsor PA, (2013). Prevalence and clinical impact of Toxocara vitulorum in cattle and buffalo calves in northern Lao PDR. Trop Anim Health Prod. 45, 539-546.
18. Raut S, Sahu RK, Mahalik A, (2016). Toxocara infestation in a suckling buffalo calf: A case report. Sch J Agric Vet Sci. 3, 123-125.

19. Rizk MA, Osman SA, Al-Gaabary MH, El-Khodery SA, (2018). Comparative clinical and parasitological efficacy of moxidectin pour-on, ivermectin, and piperazine citrate on Toxocara vitulorum infection in buffalo calves (Bubalus bubalis): a randomized clinical trial. Turk J Vet Anim Sci. 42, 29-33.

20. Roberts JA, Fernando ST, Sivanathan S, (1990). Toxocara vitulorum in the milk of buffalo (Bubalis bubalis) cows. Res Vet Sci. 49, 289-291.

21. Van Der Steen L, Pardon B, Sarre C, Valgaeren B, Van Hende D, Vlaminck L, Deprez P, (2014). Intestinal obstruction by Toxocara vitulorum in a calf. Vlaams Diergeneeskundig Tijdschrift. 83, 299-305.

22. www.tarim.gov.tr/sgb/Belgeler/SagMenuVeriler/ HAYGEM.pdf 